\title{
RESPONSES OF GROWTH PERFORMANCE, BONE MEASUREMENTS, INTESTINE MEASUREMENTS, AND PLASMA CONSTITUENTS OF MUSCOVY DUCKLINGS TO DIFFERENT LEVELS OF NONPHYTATE PHOSPHORUS AND DIETARY PHYTASE SUPPLEMENTATION DURING SUMMER SEASON
}

\author{
A. S. O. EI-Badry ${ }^{1}$, A. S. Abd EI-Hakim ${ }^{2}$ and M.H. Fatouh ${ }^{1}$ \\ 1- Department of Rabbit, Turkey and Water Fowl Breeding Research, Animal \\ Production Research Institute, Ministry of Agriculture, Dokki, Giza, Egypt, 2- \\ Poultry Nutrition Department, Animal Production Research Institute, Ministry of \\ Agriculture, Dokki, Giza, Egypt
}

\section{SUMMARY}

A total of 180 one-day old Muscovy ducklings were used in the present study to assess the effect of phytase supplementation on growth performance, feed passage time, small intestine growth, concentration of triiodothyronine $\left(T_{3}\right)$ hormone, and bone measurements during summer season.

Ducklings were divided into six equal groups. Three diets were formulated to contain $0.25 \%, 0.34 \%$ and $0.45 \%$ nonphytate phosphorus (NPP) for feeding from $1 \mathrm{~d}$ to 3 weeks of age, and $0.21,0.30$ and $0.40 \%$ NPP for feeding from 3 to 11 weeks of age, respectively. Phytase enzyme was added to all diets at two levels being. 0 and $750 \mathrm{U} K \mathrm{Kg}$. Performance results show that addition of phytase enzyme to duck diets of high NPP content significantly improved live body weight and weight gain at 1, 3, 5, 7 and (0-1), (1-3), (3-5) weeks of age, respectively. Bone ash percentages, length, width of tibia and concentration of $\mathrm{Ca}$, $P$ of tibia ash significantly increased either as dietary NPP increased or by the addition of phytase enzyme. These results clearly indicated that increasing dietary NPP level and adding phytase enzyme to duckling diets from 1 to 11 weeks of age improved weight of intestinal segments. The main effect of NPP level and phytase supplementation on duodenum morphology (villus height and crypt depth) and pH of intestinal segments significantly increased in the birds fed $100 \%$ or $75 \%$ NPP level with phytase supplementation compared with other treatments fed diets without phytase addition during summer conditions. Feed passage time was affected by dietary NPP level, however; adding phytase enzyme to duckling diets from 1 to 11 weeks of age fasted passage rate. T3 concentration did not differ significantly due to dietary NPP level with or without enzyme addition.

The present data indicate that phytase supplementation pronounced beneficial effects on growth performance, feed passage time, small intestine growth, concentrations of triiodothyronine $\left(T_{3}\right)$ hormone and bone measurements of Muscovy ducklings during summer conditions.

Keywords: Ducklings, phytase, performance

Issued by The Egyptian Society of Animal Production 


\section{INTRODUCTION}

Under Egyptian conditions during summer season, poultry production suffered from high environmental temperature which caused many troubles. Mortality was increased from heat prostration as temperature reached $38^{\circ} \mathrm{C}$ (Reece et al., 1972), reduces feed intake, growth rate and impaired feed utilization (Yalcin et al., 2001 and Attia et al., 2004). Heat stress is usually regulated by manipulation of housing conditions, genetic makeup and nutrition (Cerniglia et al., 1983; Daghir, 1995; Mendes et al., 1997; Cooper and Washburn, 1998; and Makled et al., 2001).

Nutrition manipulation of heat stress includes feeding timing (Teeter et al., 1987) quantity and quality of food, and fat supplementation (Hussein, 1996; Soliman et al., 1999; Attia et al., 2003). Critical essential amino acids (Yanming and Baker, 1993), minerals and vitamins (Moreng, 1980), and feed additives and growth promoters (Teeter, 1995) play an important role in this respect.

A number of studies have indicated that supplementing poultry diets with microbial phytase results in improved performance (van der Klis et al., 1996 and Gordon and Roland, 1998), particularly when poultry rearing during summer season (Abd El-Hakim and Abd Elsamee, 2004) or under heat stress ( Hermes and Homidan, 2003).

Several mechanisms have been proposed to explain the beneficial effects of enzymes supplementation to diets in improving performance and these include increased accessibility of nutrients to endogenous digestive enzymes, stimulation of intestinal motility, and improvement of feed passage rate (Bedford and Schulze, 1998).

Although phytase has been tested in diets of chickens (van der Klis et al., 1996 and Gordon and Roland, 1998), few research has been done with phytase in the diets of ducklings. In general, the P requirement for broiler chicks and ducklings decreases during the later growth phase from 3 to $7 \mathrm{wks}$ of age. Therefore, the use of phytase in finisher diets for ducklings should provide enough $\mathrm{P}$ to meet growth performance and bone development needs without supplementing diets with inorganic P. Phosphorus deficiency resulting in the breakage or defects of tibia and femur during processing leading to downgrading of carcass quality. Therefore, manipulations of $\mathrm{P}$ level in the diet such as adding microbial phytase to improve $\mathrm{P}$ availability have to be validated for their effects on bone status (Van der Klis et al., 1996).

The lack of information and the contradictions concerning the efficacy of phytase on the performance of ducklings reared under environmental heat stress indicate the need for more investigation. Therefore, the objective of this study was to determine the response of ducklings reared during summer season from hatching to 11 weeks of age to microbial phytase supplementation..

\section{MATERIAL AND METHODS}

The experiment was carried out in the Research Station of Waterfowls at El-Serw, Domiat Governorate, which belongs to the Animal Production Research Institute, Ministry of Agriculture, Egypt. The experiment was carried out during summer months (July, August and September, 2005). Growth performance, feed passage time, small intestine growth, concentrations of triiodothyronine $\left(\mathrm{T}_{3}\right)$ hormone, and bone measurements were determined as affected by dietary NPP level and phytase 
supplementation during summer season.

A starter $(22 \% \mathrm{CP}$ and $2900 \mathrm{Kcal} \mathrm{ME} / \mathrm{Kg})$ and a grower $(17 \% \mathrm{CP}$ and $3000 \mathrm{Kcal}$ $\mathrm{ME} / \mathrm{Kg}$ ) basal diet $(100 \%$ of requirements) were formulated with no inorganic phosphorus supplements. The starting period lasted from 1 to 14 days of age while the growing period lasted from 3 to 11 weeks of age. The nutrients content of such basal diets were adequate to cover the recommended ducklings requirements (NRC, 1994) except that of P. The calculated total P (tP) and NPP contents were 0.69 and $0.45 \%$ for the starter diet and 0.61 and $0.40 \%$ for the grower diet, respectively. Commercial dicalcium phosphate $(18.7 \% \mathrm{P}$ and $22 \% \mathrm{Ca})$ was added to formulate diets cover 75 and $50 \%$ of requirements containing 0.58 and $0.49 \%$ tP and 0.34 and $0.25 \% \mathrm{NPP}$, respectively in starter period, and 0.51 and $0.42 \%$ tP and 0.30 and $0.21 \%$ NPP, respectively in grower period. Limestone and vegetable oil were used to adjust dietary $\mathrm{Ca}$ and energy contents, respectively. Vitamin and mineral mixture was added in enough quantities to cover the ducklings requirements (NRC, 1994).

Tables ( 1 and 2$)$ show the formulation and nutrient composition of the different starter and grower diets, respectively. Phytase enzyme (Ronozyme 2500) was added $(750 \mathrm{FTU} / \mathrm{Kg}$ ) to diets 100,75 and $50 \%$ and these diets were fed with or without phytase supplementation. Thus a number of 6 diets were formulated.

Table 1. Formula and nutrient composition of starter diets

\begin{tabular}{lccc}
\hline Ingredients (\%) & $\begin{array}{c}\text { Diet } \\
\mathbf{( 1 0 0 \% )}\end{array}$ & $\begin{array}{c}\text { Diet 0.34NPP } \\
\mathbf{( 7 5 \% )}\end{array}$ & $\begin{array}{c}\text { Diet 0.25NPP } \\
\mathbf{( 5 0 \% )}\end{array}$ \\
\hline Yellow corn & 54.25 & 54.51 & 54.65 \\
Soybean meal (44\%) & 40.35 & 40.40 & 40.35 \\
Cotton seed oil & 2.06 & 1.95 & 2.00 \\
Limestone & 1.05 & 1.45 & 1.81 \\
Dicalcium phosphate & 1.60 & 1.00 & 0.50 \\
Premix* & 0.30 & 0.30 & 0.30 \\
Salt & 0.25 & 0.25 & 0.25 \\
Dl- Methionine & 0.14 & 0.14 & 0.14 \\
Total & $\mathbf{1 0 0}$ & $\mathbf{1 0 0}$ & $\mathbf{1 0 0}$ \\
Calculated composition (\%) & & & \\
Crude protein & 22.01 & 22.05 & 22.04 \\
ME (Kcal /Kg) & 2902 & 2902 & 2909 \\
Crude Fiber & 4.19 & 4.20 & 4.20 \\
Crude Fat & 4.72 & 4.62 & 4.68 \\
Calcium & 0.90 & 0.90 & 0.92 \\
Avail. P & 0.45 & 0.34 & 0.25 \\
Total P & 0.69 & 0.58 & 0.49 \\
Lysine & 1.32 & 1.32 & 1.32 \\
Methionine & 0.50 & 0.50 & 0.50 \\
Methionine + Cyctine & 0.86 & 0.86 & 0.86 \\
Sodium & 0.11 & 0.11 & 0.11 \\
\hline *Contents per 3 kg premix: Vit. A 10 M. I. U., Vit. D3 1 M. I. U., : Vit. E 10gm, : Vit. K3 1g, : Vit. B1 1g, \\
: Vit. B2 4g, N. acid 10g, P. acid 10g, Vit. B6 105g, : Vit. B12 $10 \mathrm{mg}, \mathrm{F}$ acid 1g, Biotin 50mg, Choline \\
500g, Zinc 45g, Copper 3g, Iodine 0.3g, Iron $30 \mathrm{~g}$, Selenium 0.1g, Manganese 40g and Carrier CaCo2 to \\
3000g.**According to NRC (1994) & & & \\
& & &
\end{tabular}


Table 2. Formula and nutrient composition of grower diets

\begin{tabular}{lccc}
\hline Ingredients (\%) & $\begin{array}{c}\text { Diet } \\
(\mathbf{1 0 0} \%)\end{array}$ & $\begin{array}{c}\text { Diet 0.34NPP } \\
\mathbf{( 7 5 \% )}\end{array}$ & $\begin{array}{c}\text { Diet 0.25NPP } \\
\mathbf{( 5 0 \% )}\end{array}$ \\
\hline Yellow corn & 69.13 & 69.46 & 69.43 \\
Soybean meal (44\%) & 26.50 & 26.50 & 26.50 \\
Cotton seed oil & 1.05 & 0.92 & 1.05 \\
Limestone & 1.25 & 1.60 & 2.0 \\
Dicalcium phosphate & 1.45 & 0.90 & 0.40 \\
Premix* & 0.30 & 0.30 & 0.30 \\
Salt & 0.25 & 0.25 & 0.25 \\
Dl- Methionine & 0.07 & 0.07 & 0.07 \\
Total & $\mathbf{1 0 0}$ & $\mathbf{1 0 0}$ & $\mathbf{1 0 0}$ \\
Calculated composition (\%) & & & \\
Crude protein & 17.02 & 17.05 & 17.04 \\
ME (Kcal /Kg) & 3001 & 3000 & 3010 \\
Crude Fiber & 3.52 & 3.53 & 3.53 \\
Crude Fat & 4.07 & 3.96 & 4.08 \\
Calcium & 0.90 & 0.90 & 0.90 \\
Avail. P & 0.40 & 0.30 & 0.21 \\
Total P & 0.61 & 0.51 & 0.42 \\
Lysine & 0.95 & 0.95 & 0.95 \\
Methionine & 0.37 & 0.37 & 0.37 \\
Methionine + Cyctine & 0.66 & 0.66 & 0.66 \\
Sodium & 0.11 & 0.11 & 0.11 \\
\hline *Contents per 3 kg premix: Vit. A 10 M. I. U., Vit. D3 1 M. I. U., : Vit. E 10gm, : Vit. K3 1g,: \\
Vit. B1 1g, : Vit. B2 4g, N. acid 10g, P. acid 10g, Vit. B6 105g, : Vit. B12 10mg, F. acid 1g, \\
Biotin 50mg, Choline 500g, Zinc 45g, Copper 3g, Iodine $0.3 \mathrm{~g}$, Iron 30g, Selenium 0.1g, \\
Manganese 40g and Carrier CaCo2 to 3000g.**According to NRC (1994). & \\
& & &
\end{tabular}

A number of 180 one-day old Muscovy ducklings were used. They were randomly distributed into 6 treatment groups equal in number (30 ducklings). Gas heaters were used to keep the required temperature for the brooding period while light was provided $23 \mathrm{hr}$ daily throughout the experimental period. Feed and water were allowed for ad-libitum consumption. Live body weight (BW) and feed intake (FI) were weekly recorded and body weight gain (BWG) and feed conversion ratio (FC) were calculated. At 11 weeks of age, 3 ducks were selected from each group and slaughtered for carcass characteristics and bone measurements. Breast and thigh meat were chemically analyzed for moisture, crude protein $(\mathrm{CP})$, ether extract (EE) and ash according to Official Methods of Analysis (AOAC, 1990).

Tibia of both legs were removed, cleaned of flesh and all soft tissues and ovendried at $100^{\circ} \mathrm{C}$ for $24 \mathrm{~h}$ to determine relative tibia weight (RT), tibia length (TL), and tibia width (TW). Tibia ash (TA) was determined in a muffle furnace at $600^{\circ} \mathrm{C}$ for $4 \mathrm{~h}$. Determination of phosphorus and calcium in tibia ash were carried out based on the Official Methods of Analysis (AOAC, 1990).

\section{Feed Passage Time:}

At 11 weeks of age, all groups were removed of feed $8 \mathrm{hr}$ prior to the start of a feed passage measure. All groups were fed diet containing chromic oxide $\left(\mathrm{CrO}_{2}\right)$ 
equivalent to $1 \mathrm{~g} \mathrm{CrO}_{2} / \mathrm{kg}$ of body weight. The exact time of feeding was recorded and all groups were under continuous observation to record the exact time red feces first appeared. Feed passage times were calculated by determining the difference between the exact time of feeding and the first appearance of red excreta by minute (Wilson et al., 1980).

\section{Small intestinal measurements:}

Three birds per group at 11 weeks of age were randomly selected and slaughtered to estimate the following intestinal measurements:

\section{a. Small intestine weight and length:}

The absolute length of small intestine was measured at 11 weeks of age by using ruler according to Steeb et al. (1997).

\section{b. Duodenum morphology:}

Duodenum morphology was measured as villous height (villi top) and crypt depth (villi base) in samples of mid-duodenum at 11 weeks of age. Immediately after slaughtering, samples of mid-duodenum were fixed in buffered formalin then they were embedded in paraffin wax, sectioned $\left(5^{\mu}\right)$ and stained by haematoxyline and eosin (Drury, et al., 1967). Height of villi (crypt and villous) in duodenum samples was determined using light microscope and micrometer lens and side.

\section{c. Duodenum and Jejunal pH:}

Values of $\mathrm{pH}$ of duodenum and jejunal contents were recorded at 11 weeks of age by using digital $\mathrm{pH}$-meter (Schott Gerate CG728, Germany).

\section{Blood Parameters Assay:}

Blood samples, at 11 weeks of age, were collected from wing vein into dry clean centrifuge tubes containing drops of heparin and centrifuged for 15 minutes at 3000 $\mathrm{rpm}$. The plasma samples were stored in the deep freezer at approximately $-20^{\circ} \mathrm{C}$ till the time of chemical analysis. The blood plasma concentrations of triiodothyronine $\left(\mathrm{T}_{3}\right)$ hormone were determined by radioimmunoassay technique with commercial kits (Medical Technology, USA). Sensitivity values for $T_{3}$ were measured to be $7 \mathrm{ng} / \mathrm{ml}$ approximately, Hormone levels were determined according to the procedure outlined by the manufacturer. Plasma samples were analyzed for total protein, total lipids and glucose concentrations according to Henry et al. (1974); Girard, et al. (1982) and Baure ((1982), respectively.

\section{Statistical analysis:}

Data were analyzed by the least squares analysis of variance using the General Linear Models procedure of the statistical analysis model (SAS, 2001). The statistical model was as follows: $\mathrm{Y}_{\mathrm{ijk}}=\square+\mathrm{T}_{\mathrm{i}}+\mathrm{A}_{\mathrm{j}}+\mathrm{TA}_{\mathrm{ij}}+\mathrm{e}_{\mathrm{ijk}}$
Where:
$\mathrm{Y}_{\mathrm{ijk}}=$ Observation of the $\mathrm{ij}^{\text {th }}$ duckling;
$=$ Overall mean, common element to all observations;
$\mathrm{T}_{\mathrm{i}} \quad=\quad$ Effect of dietary NPP level treatment $(\mathrm{i}=1,2,3)$;
$\mathrm{A}_{\mathrm{j}} \quad=\quad$ Effect of phytase supplementation $(\mathrm{j}=1,2)$;
$\mathrm{TA}_{\mathrm{ij}}=$ Interaction effect between $\mathrm{i}^{\text {th }}$ dietary NPP level treatment and $\mathrm{j}^{\text {th }}$ phytase supplementation;
$\mathrm{e}_{\mathrm{ijk}}=$ Random error component assumed to be normally distributed. 
Data estimated in percentage were transformed with the arcsine square-root procedure to normalize variance before analysis and were retransformed again to the original scale before presentation. The differences among means were tested using Duncan's New Multiple Range Test (Duncan, 1955).

\section{RESULTS AND DISCUSSION}

\section{Productive Performance:}

Performance (live body weight and weight gain) at all studied ages of ducks fed the 6 treatments diets during summer conditions are summarized in Tables (3) and (4).

Table 3. Live body weight (g) of ducklings as affected by dietary NPP level and phytase supplementation during summer season

\begin{tabular}{|c|c|c|c|c|c|c|}
\hline \multirow[t]{2}{*}{ Item } & \multirow{2}{*}{$\begin{array}{c}\text { Phytase } \\
\text { level }\end{array}$} & \multicolumn{3}{|c|}{ NPP level } & \multirow[t]{2}{*}{ SEM } & \multirow[t]{2}{*}{ Overall mean } \\
\hline & & $100 \%$ & $75 \%$ & $50 \%$ & & \\
\hline \multirow{3}{*}{ Day-one } & 0 & $57.3^{\mathrm{a}}$ & $57.1^{\mathrm{a}}$ & $57.8^{\mathrm{a}}$ & \multirow{2}{*}{ \pm 0.9} & $57.4^{\mathrm{a}} \pm 0.5$ \\
\hline & 750 & $57.8^{\mathrm{a}}$ & $56.7^{\mathrm{a}}$ & $57.2^{\mathrm{a}}$ & & $57.2^{\mathrm{a}} \pm 0.5$ \\
\hline & $\begin{array}{c}\text { Overall } \\
\text { mean }\end{array}$ & $57.5^{\mathrm{a}}$ & $56.9^{\mathrm{a}}$ & $57.5^{\mathrm{a}}$ & \pm 0.6 & \\
\hline \multirow{4}{*}{1 Weeks } & 0 & $130.5^{\mathrm{b}}$ & $121.7^{\mathrm{c}}$ & $115.6^{\mathrm{c}}$ & \multirow{2}{*}{ \pm 2.7} & $122.6^{\mathrm{b}} \pm 1.6$ \\
\hline & 750 & $155.2^{\mathrm{a}}$ & $137.8^{\mathrm{b}}$ & $120.6^{\mathrm{c}}$ & & $137.9^{\mathrm{a}} \pm 1.6$ \\
\hline & $\begin{array}{l}\text { Overall } \\
\text { mean }\end{array}$ & $142.8^{\mathrm{a}}$ & $129.7^{\mathrm{b}}$ & $118.1^{\mathrm{c}}$ & \pm 2.0 & \\
\hline & 0 & $537.7^{\mathrm{c}}$ & $539.6^{\mathrm{c}}$ & $518.9^{c}$ & & $532.1^{\mathrm{b}} \pm 5.8$ \\
\hline \multirow[b]{2}{*}{3 Weeks } & 750 & $641.6^{\mathrm{a}}$ & $590.4^{\mathrm{b}}$ & $535.1^{\mathrm{c}}$ & \pm 9.3 & $589^{\mathrm{a}} \pm 5.8$ \\
\hline & Overall & $589.7^{\mathrm{a}}$ & $564.9^{\mathrm{b}}$ & $527.01^{\mathrm{c}}$ & \pm 7.1 & \\
\hline \multirow{3}{*}{5 Weeks } & 0 & $1190.2^{\mathrm{ab}}$ & $1125^{\mathrm{b}}$ & $978.6^{\mathrm{b}}$ & \multirow{2}{*}{ \pm 46.3} & $1097.9^{\mathrm{a}} \pm 26.7$ \\
\hline & 750 & $1304^{\mathrm{a}}$ & $1114.5^{\mathrm{bc}}$ & $1050 b^{c}$ & & $1156.2^{\mathrm{a}} \pm 26.7$ \\
\hline & $\begin{array}{c}\text { Overall } \\
\text { mean }\end{array}$ & $1247.1^{\mathrm{a}}$ & $1119.8^{\mathrm{b}}$ & $1014.3^{c}$ & \pm 32.7 & \\
\hline \multirow{3}{*}{7 Weeks } & 0 & $2160.3^{\mathrm{a}}$ & $2100^{b}$ & $1930^{\mathrm{b}}$ & \multirow{2}{*}{ \pm 65.4} & $2063.4^{\mathrm{a}} \pm 37.5$ \\
\hline & 750 & $2240^{\mathrm{a}}$ & $2109^{\mathrm{ab}}$ & $2050^{\mathrm{b}}$ & & $2133.2^{\mathrm{a}} \pm 37.5$ \\
\hline & $\begin{array}{c}\text { Overall } \\
\text { mean }\end{array}$ & $2200^{\mathrm{a}}$ & $2104^{\mathrm{ab}}$ & $1190^{\mathrm{b}}$ & \pm 45.9 & \\
\hline \multirow{3}{*}{9 Weeks } & 0 & $2748.3^{\mathrm{a}}$ & $2627^{\mathrm{a}}$ & $2406^{\mathrm{a}}$ & \multirow{2}{*}{ \pm 130.7} & $2593.8^{\mathrm{a}} \pm 75.2$ \\
\hline & 750 & $2810^{\mathrm{a}}$ & $2513^{\mathrm{a}}$ & $2600^{\mathrm{a}}$ & & $2641.2^{\mathrm{a}} \pm 75.2$ \\
\hline & $\begin{array}{l}\text { Overall } \\
\text { mean }\end{array}$ & $2779.1^{\mathrm{a}}$ & $2570.3^{\mathrm{ab}}$ & $2503^{b}$ & \pm 42.1 & \\
\hline \multirow{3}{*}{$\begin{array}{c}11 \\
\text { Weeks }\end{array}$} & 0 & $3231.3^{\mathrm{a}}$ & $3100^{\mathrm{a}}$ & $2855^{\mathrm{a}}$ & \multirow{2}{*}{ \pm 159.0} & $3062.1^{\mathrm{a}} \pm 91.4$ \\
\hline & 750 & $3335^{\mathrm{a}}$ & $3020^{\mathrm{a}}$ & $3078^{a}$ & & $3144.3^{\mathrm{a}} \pm 91.4$ \\
\hline & $\begin{array}{c}\text { Overall } \\
\text { mean }\end{array}$ & $3283.1^{\mathrm{a}}$ & $3060^{\mathrm{a}}$ & $2966.5^{\mathrm{a}}$ & \pm 111.9 & \\
\hline
\end{tabular}

\footnotetext{
a,b,c Means with different superscripts in the same row within item differ significantly $(\mathrm{P}<0.05)$.
} 
Table 4. Weight gain of ducklings as affected by dietary NPP level and phytase supplementation during summer season

\begin{tabular}{|c|c|c|c|c|c|c|}
\hline \multirow{2}{*}{$\begin{array}{l}\text { Age } \\
\text { period }\end{array}$} & \multirow{2}{*}{$\begin{array}{c}\text { Phytase } \\
\text { level }\end{array}$} & \multicolumn{3}{|c|}{ NPP level } & \multirow[t]{2}{*}{ SEM } & \multirow[t]{2}{*}{ Overall mean } \\
\hline & & $100 \%$ & $75 \%$ & $50 \%$ & & \\
\hline \multirow{3}{*}{$\begin{array}{c}\text { One day - } \\
1 \text { Week }\end{array}$} & 0 & $73.2^{\mathrm{c}}$ & $64.6^{\mathrm{d}}$ & $57.7^{\mathrm{d}}$ & \multirow{2}{*}{ \pm 2.75} & $65.2^{\mathrm{b}} \pm 1.63$ \\
\hline & 750 & $97.4^{\mathrm{a}}$ & $81.1^{\mathrm{b}}$ & $63.4^{\mathrm{d}}$ & & $80.6^{\mathrm{a}} \pm 1.63$ \\
\hline & $\begin{array}{l}\text { Overall } \\
\text { mean }\end{array}$ & $85.3^{\mathrm{a}}$ & $72.8^{\mathrm{b}}$ & $60.5^{c}$ & \pm 2.75 & \\
\hline \multirow{3}{*}{ 1-3 weeks } & 0 & $407.3^{\mathrm{c}}$ & $417.9^{c}$ & $403.3^{\mathrm{c}}$ & \multirow[t]{2}{*}{ \pm 8.89} & $409.5^{\mathrm{b}} \pm 5.41$ \\
\hline & 750 & $486.3 \mathrm{a}$ & $432.5 b$ & $414.4 \mathrm{c}$ & & $451.2^{\mathrm{a}} \pm 5.41$ \\
\hline & $\begin{array}{l}\text { Overall } \\
\text { mean }\end{array}$ & $652.6^{\mathrm{ab}}$ & $435.2^{\mathrm{a}}$ & $408.9^{b}$ & \pm 6.63 & \\
\hline \multirow{2}{*}{ 3-5 weeks } & $\begin{array}{c}0 \\
750\end{array}$ & $\begin{array}{l}662.4^{\mathrm{a}} \\
657.4^{\mathrm{a}}\end{array}$ & $\begin{array}{l}585.3^{\mathrm{c}} \\
524.1^{\mathrm{bc}}\end{array}$ & $\begin{array}{l}459.6^{\mathrm{c}} \\
514.9^{\mathrm{bc}}\end{array}$ & \pm 46.70 & $\begin{array}{l}565.8^{\mathrm{a}} \pm 26.91 \\
467.2^{\mathrm{a}} \pm 26.91\end{array}$ \\
\hline & $\begin{array}{l}\text { Overall } \\
\text { mean }\end{array}$ & $589.7^{\mathrm{a}}$ & $554.8^{\mathrm{b}}$ & $487.3^{\mathrm{b}}$ & \pm 32.96 & \\
\hline \multirow[b]{2}{*}{5 -7Weeks } & $\begin{array}{c}0 \\
750\end{array}$ & $\begin{array}{l}970.1^{\mathrm{a}} \\
936^{\mathrm{a}}\end{array}$ & $\begin{array}{l}975^{\mathrm{a}} \\
995^{\mathrm{a}}\end{array}$ & $\begin{array}{c}951.5^{\mathrm{a}} \\
1000^{\mathrm{a}}\end{array}$ & \pm 35.22 & $\begin{array}{c}965.5^{\mathrm{a}} \pm 20.28 \\
977^{\mathrm{a}} \pm 20.2\end{array}$ \\
\hline & $\begin{array}{c}\text { Overall } \\
\text { mean }\end{array}$ & $953 .^{a}$ & $985^{\mathrm{a}}$ & $975.7^{\mathrm{a}}$ & \pm 24.84 & \\
\hline \multirow{3}{*}{ 7-9 Weeks } & 0 & $588^{\mathrm{a}}$ & $527^{\mathrm{a}}$ & $476^{\mathrm{a}}$ & \multirow{2}{*}{ \pm 74.56} & $530.3^{\mathrm{a}} \pm 43.01$ \\
\hline & 750 & $570^{\mathrm{a}}$ & $404^{\mathrm{a}}$ & $550^{\mathrm{a}}$ & & $508^{\mathrm{a}} \pm 43.01$ \\
\hline & $\begin{array}{l}\text { Overall } \\
\text { mean }\end{array}$ & $579^{\mathrm{a}}$ & $465.5^{\mathrm{a}}$ & $513^{\mathrm{a}}$ & \pm 52.66 & \\
\hline \multirow{3}{*}{$\begin{array}{c}\text { 9-11 } \\
\text { Weeks }\end{array}$} & 0 & $483^{\mathrm{a}}$ & $473^{\mathrm{a}}$ & $449^{\mathrm{a}}$ & \multirow{2}{*}{ \pm 46.70} & $468.3^{\mathrm{a}} \pm 26.73$ \\
\hline & 750 & $525^{\mathrm{a}}$ & $506.5^{\mathrm{a}}$ & $478^{\mathrm{a}}$ & & $503.2^{\mathrm{a}} \pm 26.73$ \\
\hline & $\begin{array}{c}\text { Overall } \\
\text { mean }\end{array}$ & $504^{\mathrm{a}}$ & $484.7^{\mathrm{a}}$ & $463.5^{\mathrm{a}}$ & \pm 32.7 & \\
\hline
\end{tabular}

${ }^{a, b, c}$ Means with different superscripts in the same row within age period differ significantly $(\mathrm{P}<0.05)$

Results obtained indicate that, although averages live body weight of all treatments at the beginning of the experiment at one-day were nearly similar, the increasing level of NPP in duckling diets improved body weight at 1, 3, 5, 7, and 9 weeks of age. Whereas, live body weight was significantly increased with increasing level NPP at all previous studied ages; however, this increase was not significant at 11 weeks of age. Moreover, body weight gain during periods (0-1), (1-3), (3-5), and (3-7) weeks of age was significantly higher in birds fed highest NPP level compared to those fed low dietary level NPP. However, enzyme addition to diets caused a significant higher live body weight and weight gain than the other treatments at 1,3 and (0-1), (1-3) weeks of age respectively, nevertheless live body weight and weight gain were insignificantly increased with supplemented phytase at the other ages.

The performance results of this experiment show that addition of phytase enzyme to ducklings diets of high NPP content significantly improved live body weight and weight gain at 1, 3, 5, 7 and (0-1), (1-3), (3-5) weeks of age; respectively. No significant interactions between dietary NPP level and added phytase enzyme on live body weight and weight gain of birds were detected at the other ages. 
These results are in agreement with the previous findings of Cabahug et al. (1999), Mohamed et al. (2001), Yan et al. (2001), Lan et al. (2002), Attia (2003), Wu et al. (2003), Augspurger and Baker (2004), and Onyango et al. (2004) who obtained increases in body weight gain and feed intake when microbial phytase was added to low phosphorus broiler diets. Also, Mohamed et al. (2001) reported that addition of phytase or increasing the dietary phosphorus level resulted in pronounced increases in weight gain and feed intake. Herms and Al-Homidan (2003) reported that addition of phytase enzyme at $500 \mathrm{U} / \mathrm{Kg}$ significantly improved weight gain and feed/gain ratio compared to the chicks fed diet containing 0.35 and $0.45 \%$ NPP with no phytase supplement under heat stress.

According to Simons et al. (1990), the improvements in growth observed in birds fed on a low phosphorus diet with phytase may be due to one or more of the following:

(1) an increase in absorbed phosphorus (2) the release of other minerals from the phytate mineral complex, (3) the utilization of inositol, (4) an increase in digestibility, and/or (5) increased availability of amino acids.

In conclusion, the results demonstrate that increasing dietary NPP level and phytase supplementation had appreciable effects in improving the ducklings live body weight and body weight gain during summer conditions.

\section{Carcass Characteristics at 11 Weeks of Age:}

Carcass characteristics included live body weight, percentages of dressing, abdominal fat, liver; heart and gizzard (as \% of body weight) during summer conditions at 11 weeks of age are shown in Table 5. The results indicate that increasing dietary NPP level slightly increased live body weight. Addition of phytase to diets caused slight increase in carcass weight. Such addition did not significantly affect live body weight of ducklings fed different dietary NPP levels. Increasing dietary NPP level significantly increased dressing percentage.

Addition of phytase significantly affected dressing percentage only of birds fed 100 or $75 \%$ NPP diet. Abdominal fat (as \% of body weight) was significantly affected by dietary NPP level. Birds fed the lowest NPP diet showed the lowest abdominal fat $\%$; however, those fed on higher level of NPP showed significant increase in abdominal fat $\%$.

Liver, heart and gizzard weights (as \% of body weight) of birds fed different dietary NPP levels with or without phytase addition recorded no significantly differences in all treatments. These results agree with those of Kornegay et al. (1998), Attia et al. (2001), EL-Medany and Afifi (2002), Abd-Elsamee (2002) and Salem et al. (2003) who found that phytase addition did not affect carcass characteristics. Kornegay et al. (1997) showed that carcass measurements were not affected by adding phytase of broiler fed diets containing low P. However, Viveros et al. (2002) found that decreasing NPP content of broiler diet caused an increase in relative liver weight. Phytase supplementation to low $\mathrm{P}$ diets reduced the relative liver weight by $6.3 \%$. Spleen was not affected by phytase supplementation. The interaction between NPP and phytase during summer conditions was not significant for any relative organ weight measured expect abdominal fat $\%$. 
Table 5. Carcass characteristics of ducklings as affected by dietary NPP level and phytase supplementation at 11weeks during summer season

\begin{tabular}{|c|c|c|c|c|c|c|}
\hline \multirow[t]{2}{*}{ Item } & \multirow{2}{*}{$\begin{array}{c}\text { Phytase } \\
\text { level }\end{array}$} & \multicolumn{3}{|c|}{ NPP level } & \multirow[t]{2}{*}{ SEM } & \multirow[t]{2}{*}{ Overall mean } \\
\hline & & $100 \%$ & $75 \%$ & $50 \%$ & & \\
\hline \multirow{3}{*}{$\begin{array}{c}\text { Live } \\
\text { body } \\
\text { weight }\end{array}$} & 0 & $3433.33^{\mathrm{a}}$ & $3300^{\mathrm{a}}$ & $3133.33^{\mathrm{a}}$ & \multirow{2}{*}{ \pm 438.80} & $3288.88 \pm 236.36$ \\
\hline & 750 & $3250^{\mathrm{a}}$ & $3383.33^{\mathrm{a}}$ & $3316.67^{\mathrm{a}}$ & & $3316.67^{\mathrm{a}} \pm 236.36$ \\
\hline & $\begin{array}{c}\text { Overall } \\
\text { mean }\end{array}$ & $3341.67^{\mathrm{a}}$ & $3341.67^{\mathrm{a}}$ & $3225.00^{\mathrm{a}}$ & \pm 289.49 & \\
\hline \multirow{3}{*}{$\begin{array}{c}\text { Dressing } \\
\%\end{array}$} & 0 & $68.19^{\mathrm{b}}$ & $68.20^{\mathrm{b}}$ & $67.45^{\mathrm{b}}$ & \multirow{2}{*}{ \pm 0.34} & $67.95^{\mathrm{b}}$ \\
\hline & 750 & $70.42^{\mathrm{a}}$ & $70.12^{\mathrm{a}}$ & $68.09^{\mathrm{b}}$ & & $69.54^{\mathrm{a}}$ \\
\hline & $\begin{array}{c}\text { Overall } \\
\text { mean }\end{array}$ & $69.30^{\mathrm{a}}$ & $69.17^{\mathrm{a}}$ & $67.78^{\mathrm{b}}$ & \pm 0.28 & \\
\hline \multirow{3}{*}{ Liver \% } & 0 & $1.32^{\mathrm{a}}$ & $1.31^{\mathrm{a}}$ & $1.34^{\mathrm{a}}$ & \multirow{2}{*}{ \pm 0.02} & $1.32^{\mathrm{a}} \pm 0.01$ \\
\hline & 750 & $1.35^{\mathrm{a}}$ & $1.33^{\mathrm{a}}$ & $1.32^{\mathrm{a}}$ & & $1.33^{\mathrm{a}} \pm 0.01$ \\
\hline & $\begin{array}{c}\text { Overall } \\
\text { mean }\end{array}$ & $1.34^{\mathrm{a}}$ & $1.32^{\mathrm{a}}$ & $1.73^{\mathrm{a}}$ & \pm 0.01 & \\
\hline \multirow{3}{*}{$\begin{array}{c}\text { Gizzard } \\
\%\end{array}$} & 0 & $2.98^{\mathrm{a}}$ & $3.02^{\mathrm{a}}$ & $2.98^{\mathrm{a}}$ & \multirow{2}{*}{ \pm 0.05} & $2.99^{\mathrm{a}} \pm 0.02$ \\
\hline & 750 & $2.75^{\mathrm{a}}$ & $3.05^{\mathrm{a}}$ & $2.97^{\mathrm{a}}$ & & $2.99^{\mathrm{a}} \pm 0.02$ \\
\hline & $\begin{array}{c}\text { Overall } \\
\text { mean }\end{array}$ & $2.96^{\mathrm{a}}$ & $3.03^{\mathrm{a}}$ & $2.98^{\mathrm{a}}$ & \pm 0.03 & \\
\hline \multirow{3}{*}{ Heart\% } & 0 & $0.62^{\mathrm{a}}$ & $0.63^{\mathrm{a}}$ & $0.62^{\mathrm{a}}$ & \multirow{2}{*}{ \pm 0.01} & $0.62^{\mathrm{a}} \pm 0.01$ \\
\hline & 750 & $0.61^{\mathrm{a}}$ & $0.62^{\mathrm{a}}$ & $0.61^{\mathrm{a}}$ & & $0.61^{\mathrm{a}} \pm 0.01$ \\
\hline & $\begin{array}{c}\text { Overall } \\
\text { mean }\end{array}$ & $0.61^{\mathrm{a}}$ & $0.62^{\mathrm{a}}$ & $0.61^{\mathrm{a}}$ & \pm 0.01 & \\
\hline \multirow{3}{*}{ A. Fat $\%$} & 0 & $1.86^{\mathrm{bc}}$ & $1.89^{\mathrm{b}}$ & $1.75^{\mathrm{c}}$ & \multirow{2}{*}{ \pm 0.03} & $1.83^{\mathrm{a}} \pm 0.02$ \\
\hline & 750 & $2.02^{\mathrm{a}}$ & $1.85 b^{c}$ & $1.82^{\mathrm{bc}}$ & & $1.90^{\mathrm{a}} \pm 0.02$ \\
\hline & $\begin{array}{c}\text { Overall } \\
\text { mean }\end{array}$ & $1.94^{\mathrm{a}}$ & $1.87^{\mathrm{ab}}$ & $1.79^{\mathrm{b}}$ & \pm 0.03 & \\
\hline
\end{tabular}

${ }^{a, b, c}$ Means with different superscripts in the same row within item differ significantly $(\mathrm{P}<0.05)$.

\section{Meat Analysis:}

The effects of dietary NPP level and phytase supplementation on chemical composition of meat of 11 weeks old ducks fed the different treatments diets during summer conditions are shown in Table 6. The results indicate that increasing NPP levels had resulted in decreased moisture of meat. There were significant effects on moisture content of meat with the addition of phytase. Supplementation of phytase significantly increased the moisture content of meat.

Protein and ash of meat were not affected by either dietary NPP level or phytase supplementation. Also, ether extract was not affected by dietary NPP level; however, phytase supplementation significantly increased ether extract (EE) of meat. The change in EE was parallel to the increase in abdominal fat and was in contrary to the change in percentage of protein in meat. These results are in partial agreement with Qota et al. (2002), Attia et al. (2003), El-Nagmy et al. (2004) and Ibrahem (2006) who reported that phytase supplementation to broiler diets had no significant effect on chemical composition of meat. Abd-Elsamee (2002) reported that there were no significant differences in meat analysis value due to phytase supplementation of broiler chicks. 
Table 6. Meat chemical composition of ducklings as affected by dietary NPP level and phytase supplementation during summer season

\begin{tabular}{|c|c|c|c|c|c|c|}
\hline \multirow[t]{2}{*}{ Item } & \multirow{2}{*}{$\begin{array}{c}\text { Phytase } \\
\text { level }\end{array}$} & \multicolumn{3}{|c|}{ NPP level } & \multirow[t]{2}{*}{ SEM } & \multirow[t]{2}{*}{ Overall mean } \\
\hline & & $100 \%$ & $75 \%$ & $50 \%$ & & \\
\hline \multirow{3}{*}{$\begin{array}{c}\text { Moisture } \\
\%\end{array}$} & 0 & $75.95^{\mathrm{ab}}$ & $75.95^{\mathrm{ab}}$ & $76.46^{\mathrm{a}}$ & \multirow{2}{*}{ \pm 0.24} & $76.12^{\mathrm{a}} \pm 0.14$ \\
\hline & 750 & $75.82^{\mathrm{ab}}$ & $75.18^{\mathrm{b}}$ & $75.88^{\mathrm{ab}}$ & & $75.63^{\mathrm{b}} \pm 0.14$ \\
\hline & Overall & $75.89^{\mathrm{b}}$ & $75.56^{\mathrm{b}}$ & $76.17^{\mathrm{a}}$ & \pm 0.17 & \\
\hline \multirow{3}{*}{$\begin{array}{c}\text { Crude } \\
\text { Protein \% }\end{array}$} & 0 & $20.57^{\mathrm{a}}$ & $20.67^{\mathrm{a}}$ & $20.28^{\mathrm{a}}$ & \multirow{2}{*}{ \pm 0.28} & $20.51^{\mathrm{a}} \pm 0.15$ \\
\hline & 750 & $20.80^{\mathrm{a}}$ & $20.77^{\mathrm{a}}$ & $20.81^{\mathrm{a}}$ & & $20.79 \pm 0.15$ \\
\hline & $\begin{array}{c}\text { Overall } \\
\text { mean }\end{array}$ & $20.68^{\mathrm{a}}$ & $20.72^{\mathrm{a}}$ & $20.54^{\mathrm{a}}$ & \pm 0.19 & \\
\hline \multirow{3}{*}{$\begin{array}{c}\text { Ether } \\
\text { Extract \% }\end{array}$} & 0 & $2.52^{\mathrm{a}}$ & $2.55^{\mathrm{a}}$ & $2.35^{\mathrm{a}}$ & \multirow{2}{*}{ \pm 0.14} & $2.47^{\mathrm{b}} \pm 0.07$ \\
\hline & 750 & $2.82^{\mathrm{a}}$ & $2.73^{\mathrm{a}}$ & $2.59^{\mathrm{a}}$ & & $2.71^{\mathrm{a}} \pm 0.07$ \\
\hline & $\begin{array}{c}\text { Overall } \\
\text { mean }\end{array}$ & $2.67^{\mathrm{a}}$ & $2.64^{\mathrm{a}}$ & $2.47^{\mathrm{a}}$ & \pm 0.09 & \\
\hline \multirow{2}{*}{ Ash \% } & $\begin{array}{c}0 \\
750\end{array}$ & $\begin{array}{l}0.96^{\mathrm{a}} \\
0.55^{\mathrm{a}}\end{array}$ & $\begin{array}{l}0.83^{\mathrm{a}} \\
1.14^{\mathrm{a}}\end{array}$ & $\begin{array}{l}0.93^{\mathrm{a}} \\
0.71^{\mathrm{a}}\end{array}$ & \pm 0.31 & $\begin{array}{l}0.91^{\mathrm{a}} \pm 0.18 \\
0.85^{\mathrm{a}} \pm 0.18\end{array}$ \\
\hline & $\begin{array}{c}\text { Overall } \\
\text { mean }\end{array}$ & $0.75^{\mathrm{a}}$ & $0.98^{\mathrm{a}}$ & $0.88^{\mathrm{a}}$ & \pm 0.21 & \\
\hline
\end{tabular}

It could be concluded that there were no significant differences in meat crude protein, ether extract and ash during summer conditions that may be due to NPP level and phytase supplementation. However, the ducklings fed the lowest dietary NPP level recorded the maximum moisture of meat.

\section{Bone Measurements at 11 weeks of Age:}

The effects of dietary NPP level and phytase supplementation on bone measurements of 11 weeks old ducklings fed the different treatments diets during summer conditions are shown in Table 7.

Increasing dietary NPP level from 50 or 75 to $100 \%$ without or with added phytase enzyme significantly increased length of tibia. No significant differences in tibia length were detected between birds fed levels of NPP with phytase and birds fed levels of NPP without phytase supplementation. Qian et al. (1996) found that supplemental phytase and inorganic phosphorus increased tibia length, and bone ash content of broiler chicks.

The main effect of NPP level and phytase supplementation on tibia length and width during summer conditions shows that the length and width of tibia significantly increased as dietary NPP increased or by the supplementation of phytase enzyme. Tibia weight was significantly increased with increasing dietary NPP levels or phytase supplementation of phytase significantly increased tibia weight.

Birds fed the lowest dietary NPP level recorded the minimum ash percentage of tibia. The maximum ash percentages were recorded for birds fed diet containing 75 or $100 \%$ NPP plus phytase.

The main effects show that increasing dietary NPP level and phytase supplementation significantly increased bone ash percentages. No significant 
difference in bone ash percentages was detected between birds fed 75 or $100 \%$ NPP. Significant interaction between NPP level and phytase supplementation was detected in weight and ash of tibia.

It could be concluded, therefore, that increasing dietary non-phytate $\mathrm{P}$ or added phytase enzyme to low $\mathrm{P}$ diets increased percentages of bone ash of ducklings especially during summer conditions.

\section{Tibia Mineral Concentrations:}

The effects of dietary NPP level and phytase supplementation on concentrations of $\mathrm{Ca}, \mathrm{P} \%$ in tibia ash during summer conditions are presented in Table 7.

Table 7. Bone Measurements of ducklings as affected by dietary NPP level and phytase supplementation during summer season

\begin{tabular}{|c|c|c|c|c|c|c|}
\hline \multirow[t]{2}{*}{ Item } & \multirow{2}{*}{$\begin{array}{c}\text { Phytase } \\
\text { level }\end{array}$} & \multicolumn{3}{|c|}{ NPP level } & \multirow{2}{*}{ SEM } & \multirow{2}{*}{ Overall mean } \\
\hline & & $100 \%$ & $75 \%$ & $50 \%$ & & \\
\hline \multirow{3}{*}{$\begin{array}{c}\text { Tibia Bone } \\
\text { Length } \\
\text { (cm) }\end{array}$} & 0 & $11.9^{\mathrm{a}}$ & $10.7^{\mathrm{b}}$ & $9.5^{\mathrm{c}}$ & \multirow{2}{*}{ \pm 0.25} & $10.7^{\mathrm{a}} \pm 0.21$ \\
\hline & 750 & $11.2^{\mathrm{ab}}$ & $11.4^{\mathrm{ab}}$ & $10.6^{\mathrm{b}}$ & & $11.1^{\mathrm{a}} \pm 0.21$ \\
\hline & $\begin{array}{c}\text { Overall } \\
\text { mean }\end{array}$ & $11.5^{\mathrm{a}}$ & $11^{\mathrm{a}}$ & $10^{\mathrm{b}}$ & \pm 0.24 & \\
\hline \multirow{3}{*}{$\begin{array}{l}\text { Tibia Bone } \\
\text { Width } \\
\text { (cm) }\end{array}$} & 0 & $1.07^{\mathrm{a}}$ & $0.86^{\mathrm{b}}$ & $0.83^{\mathrm{b}}$ & \multirow{2}{*}{ \pm 0.02} & $0.92^{\mathrm{a}} \pm 0.02$ \\
\hline & 750 & $0.99^{\mathrm{a}}$ & $0.98^{\mathrm{a}}$ & $0.89^{\mathrm{b}}$ & & $0.96^{\mathrm{a}} \pm 0.02$ \\
\hline & $\begin{array}{c}\text { Overall } \\
\text { mean }\end{array}$ & $1.03^{\mathrm{a}}$ & $0.92^{\mathrm{b}}$ & $0.86^{\mathrm{b}}$ & \pm 0.03 & \\
\hline \multirow{3}{*}{$\begin{array}{c}\text { Weight } \\
\text { Tibia Bone } \\
\text { (g) }\end{array}$} & 0 & $12.1^{\mathrm{a}}$ & $11.3^{\mathrm{b}}$ & $10.7^{\mathrm{c}}$ & \multirow{2}{*}{ \pm 0.18} & $11.3^{\mathrm{b}} \pm 0.12$ \\
\hline & 750 & $12.2^{\mathrm{a}}$ & $11.9^{\mathrm{b}}$ & $11.7^{\mathrm{b}}$ & & $11.9^{\mathrm{a}} \pm 0.12$ \\
\hline & $\begin{array}{c}\text { Overall } \\
\text { mean }\end{array}$ & $12.2^{\mathrm{a}}$ & $11.6^{\mathrm{b}}$ & $11.2^{\mathrm{c}}$ & \pm 0.15 & \\
\hline \multirow{3}{*}{ Са \% } & 0 & $30.7^{\mathrm{a}}$ & $28.1^{\mathrm{bc}}$ & $25.7^{\mathrm{d}}$ & \multirow{2}{*}{ \pm 0.60} & $28.1^{\mathrm{a}} \pm 0.46$ \\
\hline & 750 & $29.0^{\mathrm{abc}}$ & $29.8^{\mathrm{ab}}$ & $26.9^{\text {cd }}$ & & $28.8^{\mathrm{a}} \pm 0.46$ \\
\hline & $\begin{array}{c}\text { Overall } \\
\text { mean }\end{array}$ & $29.86^{\mathrm{a}}$ & $29.01^{\mathrm{a}}$ & $26.29^{b}$ & \pm 0.53 & \\
\hline \multirow{3}{*}{ P \% } & 0 & $14.9^{\mathrm{a}}$ & $13.9^{\mathrm{ab}}$ & $13^{\mathrm{b}}$ & \multirow{2}{*}{ \pm 0.37} & $13.9^{a} \pm 0.25$ \\
\hline & 750 & $14.1^{\mathrm{ab}}$ & $14.8^{\mathrm{a}}$ & $13.5^{\mathrm{ab}}$ & & $14.2^{\mathrm{a}} \pm 0.25$ \\
\hline & $\begin{array}{l}\text { Overall } \\
\text { mean }\end{array}$ & $14.5^{\mathrm{a}}$ & $14.4^{\mathrm{a}}$ & $13.2^{\mathrm{b}}$ & \pm 0.29 & \\
\hline \multirow{3}{*}{$\begin{array}{c}\text { Bone ash } \\
\%\end{array}$} & 0 & $43.2^{\mathrm{a}}$ & $40.7^{\mathrm{ab}}$ & $38.5^{\mathrm{ab}}$ & \multirow{2}{*}{ \pm 0.95} & $40.8^{\mathrm{a}} \pm 0.56$ \\
\hline & 750 & $42.9^{\mathrm{a}}$ & $42.8^{\mathrm{a}}$ & $40.8^{\mathrm{ab}}$ & & $42.3^{\mathrm{a}} \pm 0.56$ \\
\hline & $\begin{array}{c}\text { Overall } \\
\text { mean }\end{array}$ & $43.1^{\mathrm{a}}$ & $41.8^{\mathrm{a}}$ & $39.6^{\mathrm{b}}$ & \pm 0.68 & \\
\hline
\end{tabular}

a,b,c Means with different superscripts in the same row within item differ significantly $(\mathrm{P}<0.05)$.

The main effects of NPP level on concentration of $\mathrm{Ca}, \mathrm{P}$ of tibia ash show that increasing NPP from 50 to 75 or $100 \%$ significantly increased $\mathrm{Ca}$ and $\mathrm{P} \%$. Moreover, phytase supplementation significantly increased $\mathrm{Ca}, \mathrm{P}$ concentrations.

These results clearly indicate that increasing dietary NPP level or supplementing phytase enzyme to ducklings diets from 1 to 11 weeks of age improved bone mineralization during summer season. The improvement in tibia ash percentage could be considered as a good indication of increased bone mineralization (Sebastian et al., 
1996). The results of these authors indicate that phytase supplementation to a low-P corn-soybean broiler diet improved percentages of tibia ash and apparent availability of $\mathrm{Ca}, \mathrm{P}, \mathrm{Cu}$ and $\mathrm{Zn}$.

The results of bone measurements are in agreement with the previous results of Qian et al. (1996), Sebastian et al. (1996), Carlos and Edwards (1997), Mohamed et al. (2001), Lan et al. (2002), Viveros et al. (2002), Wu et al. (2003) and Augspurger and Baker (2004).

\section{Weight and length of intestinal:}

The effects of dietary NPP level and phytase supplementation on weight and length of intestinal segments at 11 weeks old ducklings during summer conditions are shown in Table (8). The results indicate that increasing NPP level significantly increased weight of duodenum with no effect on jejunum and ileum weights. Phytase supplementation significantly increased weights of all intestinal segments. However, length of small intestine was not affected by either dietary NPP level or phytase supplementation.

Table 8. Weights, lengths and morphology of ducklings small intestine as affected by dietary NPP level and phytase supplementation during summer season

\begin{tabular}{|c|c|c|c|c|c|c|}
\hline \multirow[t]{2}{*}{ Item } & \multirow{2}{*}{$\begin{array}{c}\text { Phytase } \\
\text { level }\end{array}$} & \multicolumn{3}{|c|}{ NPP level } & \multirow[t]{2}{*}{ SEM } & \multirow[t]{2}{*}{ Overall mean } \\
\hline & & $100 \%$ & $75 \%$ & $50 \%$ & & \\
\hline \multirow{3}{*}{$\begin{array}{l}\text { Duodenum } \\
\text { weight (g) }\end{array}$} & 0 & $7.5^{\mathrm{ab}}$ & $7.0^{\mathrm{b}}$ & $7.1^{\mathrm{b}}$ & \multirow{2}{*}{ \pm 0.19} & $7.2^{\mathrm{b}} \pm 0.12$ \\
\hline & 750 & $8.2^{\mathrm{a}}$ & $7.8^{\mathrm{a}}$ & $7.1^{\mathrm{b}}$ & & $7.8^{\mathrm{a}} \pm 0.12$ \\
\hline & $\begin{array}{c}\text { Overall } \\
\text { mean }\end{array}$ & $7.8^{\mathrm{a}}$ & $7.5^{\mathrm{ab}}$ & $7.2^{\mathrm{b}}$ & \pm 0.15 & \\
\hline \multirow{3}{*}{$\begin{array}{l}\text { Jejunum } \\
\text { and ileum } \\
\text { weight } \underline{(g)}\end{array}$} & 0 & $17.7^{\mathrm{b}}$ & $17.8^{\mathrm{b}}$ & $17.6^{\mathrm{b}}$ & \multirow{2}{*}{ \pm 0.32} & $17.7^{\mathrm{b}} \pm 0.20$ \\
\hline & 750 & $19.0^{\mathrm{a}}$ & $18.4^{\mathrm{ab}}$ & $17.8^{\mathrm{b}}$ & & $18.5^{\mathrm{a}} \pm 0.20$ \\
\hline & $\begin{array}{c}\text { Overall } \\
\text { mean }\end{array}$ & $18.4^{\mathrm{a}}$ & $18.1^{\mathrm{a}}$ & $17.7^{\mathrm{a}}$ & \pm 0.24 & \\
\hline \multirow{3}{*}{$\begin{array}{l}\text { Duodenum } \\
\text { length (cm) }\end{array}$} & 0 & $12.2^{\mathrm{a}}$ & $12.4^{\mathrm{a}}$ & $12.1^{\mathrm{a}}$ & \multirow{2}{*}{ \pm 0.27} & $12.2^{\mathrm{a}} \pm 0.15$ \\
\hline & 750 & $12.6^{\mathrm{a}}$ & $12.2^{\mathrm{a}}$ & $12.3^{\mathrm{a}}$ & & $12.3^{\mathrm{a}} \pm 0.15$ \\
\hline & $\begin{array}{c}\text { Overall } \\
\text { mean }\end{array}$ & $12.4^{\mathrm{a}}$ & $12.1^{\mathrm{a}}$ & $12.2^{\mathrm{a}}$ & \pm 0.18 & \\
\hline \multirow{3}{*}{$\begin{array}{c}\text { Jejunum } \\
\text { and ileum } \\
\text { length (cm) }\end{array}$} & 0 & $62.3^{\mathrm{a}}$ & $62.4^{\mathrm{a}}$ & $62.6^{\mathrm{a}}$ & \multirow{2}{*}{ \pm 0.34} & $62.4^{\mathrm{a}} \pm 0.18$ \\
\hline & 750 & $62.4^{\mathrm{a}}$ & $62.5^{\mathrm{a}}$ & $62.3^{\mathrm{a}}$ & & $62.4^{\mathrm{a}} \pm 0.18$ \\
\hline & $\begin{array}{c}\text { Overall } \\
\text { mean }\end{array}$ & $62.4^{\mathrm{a}}$ & $62.4^{\mathrm{a}}$ & $62.5^{\mathrm{a}}$ & \pm 0.23 & \\
\hline \multirow{3}{*}{$\begin{array}{l}\text { Crypt depth } \\
\quad(\mathrm{mm})\end{array}$} & 0 & $121.5^{\mathrm{b}}$ & $121.0^{\mathrm{b}}$ & $124.6^{\mathrm{b}}$ & \multirow{2}{*}{ \pm 2.48} & $122.3^{\mathrm{b}} \pm 1.69$ \\
\hline & 750 & $133.4^{\mathrm{a}}$ & $132.6^{\mathrm{a}}$ & $124.6^{\mathrm{b}}$ & & $130.2^{\mathrm{a}} \pm 1.69$ \\
\hline & $\begin{array}{c}\text { Overall } \\
\text { mean }\end{array}$ & $127.4^{\mathrm{a}}$ & $126.7^{\mathrm{a}}$ & $124.6^{\mathrm{a}}$ & \pm 2.07 & \\
\hline \multirow{3}{*}{$\begin{array}{c}\text { Villous } \\
\text { height (mm) }\end{array}$} & 0 & $0.8^{\mathrm{c}}$ & $0.8^{\mathrm{c}}$ & $0.8^{\mathrm{c}}$ & \multirow{2}{*}{ \pm 0.02} & $0.8^{\mathrm{b}} \pm 0.01$ \\
\hline & 750 & $1.0^{\mathrm{a}}$ & $0.9^{\mathrm{b}}$ & $0.9^{\mathrm{c}}$ & & $1.0^{\mathrm{a}} \pm 0.01$ \\
\hline & $\begin{array}{c}\text { Overall } \\
\text { mean }\end{array}$ & $0.9^{\mathrm{a}}$ & $0.9^{\mathrm{b}}$ & $0.9^{\mathrm{b}}$ & \pm 0.01 & \\
\hline
\end{tabular}


intestinal segments.

The explanation for the relatively heavier intestinal weight of birds fed the enzymes supplementation diets probably lies in the increased digesta viscosity reduced intestinal mobility with increasing in microbial activity that stimulate intestinal tissue growth (Brenes et al., 2002).

\section{Duodenum morphology:}

Duodenum morphology was measured as villous height (villi top) and crypt depth (villi base) at 11 weeks of age. Data in Table (9) show that villous height did not differ significantly by dietary NPP level. and villous height for the groups fed the highest dietary NPP level was insignificantly higher than the other treatments. However, enzyme supplementation to the diets caused significant higher values for this parameter than the other treatments.

Table 9. Small intestinal pH and feed passage time in ducklings as affected by dietary NPP level and phytase supplementation during summer season

\begin{tabular}{|c|c|c|c|c|c|c|}
\hline \multirow[t]{2}{*}{ Item } & \multirow{2}{*}{$\begin{array}{l}\text { Phytase } \\
\text { level }\end{array}$} & \multicolumn{3}{|c|}{ NPP level } & \multirow[t]{2}{*}{ SEM } & \multirow[t]{2}{*}{ Overall mean } \\
\hline & & $100 \%$ & $75 \%$ & $50 \%$ & & \\
\hline \multirow{3}{*}{$\underset{\text { pH }}{\text { duodenum }}$} & 0 & $6.12^{\mathrm{c}}$ & $6.05^{\mathrm{c}}$ & $6.09^{c}$ & \multirow{2}{*}{ \pm 0.07} & $6.09^{\mathrm{b}} \pm 0.07$ \\
\hline & 750 & $6.71^{\mathrm{a}}$ & $6.35^{\mathrm{b}}$ & $6.10^{\mathrm{c}}$ & & $6.42^{\mathrm{a}} \pm 0.07$ \\
\hline & $\begin{array}{c}\text { Overall } \\
\text { mean }\end{array}$ & $6.42^{\mathrm{a}}$ & $6.21^{b}$ & $6.13^{b}$ & \pm 0.07 & \\
\hline \multirow{3}{*}{$\begin{array}{c}\text { pH } \\
\text { jejunum }\end{array}$} & 0 & $6.32^{\mathrm{b}}$ & $6.49^{b}$ & $6.33^{b}$ & \multirow{2}{*}{ \pm 0.07} & $6.38^{\mathrm{b}} \pm 0.07$ \\
\hline & 750 & $6.85^{\mathrm{a}}$ & $6.84^{\mathrm{a}}$ & $6.40^{\mathrm{b}}$ & & $6.72^{\mathrm{a}} \pm 0.07$ \\
\hline & $\begin{array}{c}\text { Overall } \\
\text { mean }\end{array}$ & $6.59^{\mathrm{a}}$ & $6.67^{\mathrm{a}}$ & $6.29^{b}$ & \pm 0.07 & \\
\hline \multirow{3}{*}{$\begin{array}{l}\text { Feed passage } \\
\text { time (min.) }\end{array}$} & 0 & $142^{\mathrm{a}}$ & $140^{\mathrm{a}}$ & $140^{\mathrm{a}}$ & \multirow{2}{*}{ \pm 1.92} & $141^{\mathrm{a}} \pm 1.26$ \\
\hline & 750 & $124^{\mathrm{c}}$ & $126^{b c}$ & $132^{\mathrm{b}}$ & & $127^{\mathrm{b}} \pm 1.26$ \\
\hline & $\begin{array}{c}\text { Overall } \\
\text { mean }\end{array}$ & $133^{\mathrm{a}}$ & $133^{\mathrm{a}}$ & $135^{\mathrm{a}}$ & \pm 1.55 & \\
\hline
\end{tabular}

On the other hand, crypt depth was affected by dietary NPP level. Whereas, crypt depth was significantly increased with increasing dietary NPP level Phytase supplementation to the diets caused a significant higher values in this parameter than the other treatments. These results are in agreement with $\mathrm{Wu}$, et al., (2004) who reported that microbial phytase increased villus height in the duodenum, but had no effect on villus height in the jejunum or ileum. The increase in the height and therefore in the surface area of duodenal villi may partially explain the better performance observed in the phytase-supplemented group. The villi height in the duodenum was greater than those in the jejunum and ileum, and this is in agreement with the significant role that the duodenum plays in nutrient absorption.

The main effect of NPP level and phytase supplementation on duodenum morphology significantly increased villus height and crypt depth in ducklings fed 100 or $75 \%$ NPP level with phytase supplementation compared to the other treatments fed diets without phytase supplementation during summer conditions. 
pH:

The effects of dietary NPP level and phytase supplementation on $\mathrm{pH}$ of intestinal segments at 11 weeks old ducklings fed the different treatments diets during summer conditions are shown in Table (9). The results indicate that increasing NPP levels significantly increased $\mathrm{pH}$ of duodenum and jejunum. The significant effects were observed among treatments fed diets with phytase addition. These results are in agreement with those of Shafey et al. (1991).

From the previous results, it could be suggested that any tendency towards an increase in intestinal $\mathrm{pH}$ in response to high calcium and phosphorus intake may be balanced by a decrease in the secretion of the alkaline components of intestinal juice. It could be concluded that the increase in intestinal $\mathrm{pH}$ by phytase supplementation may be attributed to optimum enzymes activity and its influence on absorption of some metabolic ions.

The main effect of NPP level and phytase supplementation on $\mathrm{pH}$ of intestinal segments significantly increased only in birds fed 100 or $75 \%$ NPP level plus phytase supplementation compared to other treatments fed diets without phytase addition during summer conditions.

\section{Feed passage time:}

The effects of dietary NPP level and phytase supplementation on feed passage time at 11 weeks old ducklings during summer conditions are shown in Table (9). The results indicate that passage time was not significantly affected by dietary NPP level However, phytase supplementation significantly improved passage rate compared with other treatments fed diets without phytase addition. This result is agreement with Watson et al. (2006) who reported that chicks fed phytase showed faster transit time of feed through the digestive tract and resulting in a greater feed intake and gain.

The main effect of NPP level and phytase supplementation on passage time show that passage rate was not affected by dietary NPP level but added phytase enzyme to duckling diets from 1 to 11 weeks of age shortened passage time during summer conditions.

\section{Blood parameters:}

Data in Table (10) show that T3 concentration did not differ significantly by dietary NPP level without or with enzyme addition. However, T3 concentration for the groups fed the lowest dietary NPP level was insignificantly higher than the other treatments. Thyroid hormones have a major role in the regulation of protein metabolism as well as energy metabolism, and protein turnover, especially in skeletal muscles, (Hayashi et al., 1992). Therefore, it is conceivable that thyroid hormones is necessary for normal growth and development particularly that of bone and muscle, (Harden and Oscar, 1993).

Total plasma protein was significantly increased by the dietary NPP level. Whereas, enzyme addition to the diets caused a significant higher increase in this blood parameter than the other treatments. The increase in total plasma protein may be attributed to increase in protein consumption and digestibility in those treatments and thus in rate of metabolism. Phytase may increase the activity of proteolytic enzymes (pepsin, trypsin and $\alpha$-amylase) by releasing calcium from phytate-minerals 
complexes which are essential for the activity of these enzymes.

Table 10. Blood parameters of ducklings as affected by dietary NPP level and phytase supplementation during summer season

\begin{tabular}{|c|c|c|c|c|c|c|}
\hline \multirow[t]{2}{*}{ Item } & \multirow{2}{*}{$\begin{array}{c}\text { Phytase } \\
\text { level }\end{array}$} & \multicolumn{3}{|c|}{ NPP level } & \multirow[t]{2}{*}{ SEM } & \multirow[t]{2}{*}{ Overall mean } \\
\hline & & $100 \%$ & $75 \%$ & $50 \%$ & & \\
\hline \multirow{3}{*}{$\begin{array}{c}\text { Total } \\
\text { protein } \\
\text { g/100ml }\end{array}$} & 0 & $4.6^{\mathrm{a}}$ & $4.68^{\mathrm{a}}$ & $4.2^{\mathrm{b}}$ & \multirow{2}{*}{ \pm 0.03} & $4.5^{\mathrm{b}} \pm 0.03$ \\
\hline & 750 & $4.7^{\mathrm{a}}$ & $4.7^{\mathrm{a}}$ & $4.6^{\mathrm{a}}$ & & $4.7^{\mathrm{a}} \pm 0.03$ \\
\hline & Overall & $4.6^{\mathrm{a}}$ & $4.6^{\mathrm{a}}$ & $4.4^{\mathrm{b}}$ & \pm 0.04 & \\
\hline \multirow{3}{*}{$\begin{array}{c}\text { Total lipids } \\
\text { mg/100ml }\end{array}$} & 0 & $532.1^{\mathrm{b}}$ & $535.0^{\mathrm{b}}$ & $503.3^{\mathrm{c}}$ & \multirow{2}{*}{ \pm 3.75} & $523.5^{\mathrm{b}} \pm 2.77$ \\
\hline & 750 & $555.5^{\mathrm{a}}$ & $538.7^{\mathrm{b}}$ & $539.0^{\mathrm{b}}$ & & $544.4^{\mathrm{a}} \pm 2.77$ \\
\hline & $\begin{array}{c}\text { Overall } \\
\text { mean }\end{array}$ & $543.8^{\mathrm{a}}$ & $536.8^{\mathrm{a}}$ & $521.12^{b}$ & \pm 3.39 & \\
\hline \multirow{3}{*}{$\begin{array}{c}\text { Glucose } \\
\text { mg/100ml }\end{array}$} & 0 & $233.2^{\mathrm{b}}$ & $231.5^{\mathrm{b}}$ & $207.3^{\mathrm{c}}$ & \multirow{2}{*}{ \pm 2.77} & $223.9^{\mathrm{b}} \pm 2.03$ \\
\hline & 750 & $253.7^{\mathrm{a}}$ & $239.7^{\mathrm{b}}$ & $238.8^{\mathrm{b}}$ & & $244.1^{\mathrm{a}} \pm 2.03$ \\
\hline & $\begin{array}{l}\text { Overall } \\
\text { mean }\end{array}$ & $243.5^{\mathrm{a}}$ & $235.6^{\mathrm{b}}$ & $223.0^{\mathrm{c}}$ & \pm 2.48 & \\
\hline \multirow{3}{*}{ T3 ng/dl } & 0 & $128.8^{\mathrm{b}}$ & $128.6^{\mathrm{b}}$ & $141.9^{\mathrm{ab}}$ & \multirow{2}{*}{ \pm 4.73} & $133.1^{\mathrm{a}} \pm 2.77$ \\
\hline & 750 & $136.9^{\mathrm{b}}$ & $144.3^{\mathrm{a}}$ & $138.3^{\mathrm{ab}}$ & & $139.8^{\mathrm{a}} \pm 2.77$ \\
\hline & $\begin{array}{l}\text { Overall } \\
\text { mean }\end{array}$ & $132.9^{\mathrm{a}}$ & $136.4^{\mathrm{a}}$ & $138.1^{\mathrm{a}}$ & \pm 3.48 & \\
\hline
\end{tabular}

a,b,c Means with different superscripts in the same row within item differ significantly $(\mathrm{P}<0.05)$

Furthermore, from the data it was detected that lipids and glucose concentrations in plasma were affected by dietary NPP level. Whereas those blood parameters were significantly increased with increasing dietary NPP level; however, enzyme addition to the diets caused a significant higher values for those blood parameters than the other treatments. Also, data in Table (10) show the effect of interaction between dietary NPP level and phytase supplementation during summer season on those blood parameters. Whereas enzyme supplementation at the highest NPP level to the diets resulted in a significant higher values of these blood parameters than the other treatments.

It can be concluded that the results obtained in this study draw attention to the beneficial effect of phytase supplementation during summer conditions to the diets of ducklings.

\section{REFERENCES}

Abd El-Hakim, A. S. and M.O. Abd El-Samee, 2004. Effect of feeding system and phytase supplementation on performance of broiler chicks during summer season. Egypt. Poult. Sci. 24: 297-310.

Abd El-Samee, M.O., 2002. Effect of different levels of crude protein, sulphur amino acids, microbial phytase and their interaction on broiler chick performance. Egypt. Poult. Sci. J., 22: 999-1021.

Association of Official Analytical Chemists, A.O.A.C., 1990. Official Methods of Analysis. $15^{\text {th }}$ ed., Association of Official Analytical Chemists. Washington, DC. 
Attia, A. I., I.I. Hassan, A.A. El-Zaiat, and A.A. Abd El-Maksoud, 2003. Effects of dietary oil and ascorbic acid on the performance of broiler chicks under Egyptian summer conditions. Egyptian J. Nutr. and Feeds (2003) 6 (Special Issue):3-4.

Attia, Y. A, F.A.M Aggoor.; E. M. A. Qota, Qota; and M. A. Hayam Abo El-Maaty, 2003. Effect of dietary crude protein level and source and phytase addition on productive performance, carcass and plasma constituents of roasters. Egyption J. Nut. and Feed. 6 (Special issue) 61-75.

Attia, Y. A., 2003. Responses of growth performance, carcass characteristics, meat quality and plasma constituents of male Campbell ducks to dietary levels of methionine and phytase and their interactions. Egypt. Poult. Sci. J., 23: 557-580.

Attia, Y. A., S. A. Abd-Elrhaman and E. M. Qota, 2001. Effects of microbial phytase without or with cell wall splitting enzymes on the performance of broiler fed marginal levels of dietary protein and metabolizable energy. Egypt. Poult. Sci. J., 21: 521-547.

Augspurger, N. R. and, D. H. Baker, 2004. High dietary phytase levels maximize phytate-phosphorus utilization but not affect protein utilization in chicks fed phosphorus or amino acid-deficient diets. J. Anim. Sci., 82: 1100-1107.

Baure, J.D., 1982. Clinical Laboratory Methods Mobs. C. U., USA 9 ${ }^{\text {th }}$, 1121: 495496.

Bedford, M. R. and H. Schuize, 1998. Exogenous enzymes for pigs and poultry. Nutrition Research Reviews. 11: 91-114.

Brenes, A.;, R. R. Marquardt; W. Guener and A. Viveros, 2002. Effect of enzyme addition on the performance and gastrointestinal tract size of chicks fed lupin seed and their fractions. Poultry Sci., 81: 670-678.

Cabahug, S.; V. Ravindran,; P. H. Selle and W. L. Bryden, 1999. Response of broiler chickens to microbial phytase supplementation as influenced by dietary phytic acid and nonphytate phosphorus contents. 1. Effects on bird performance and toe ash. Br. Poult. Sci., 40: 660-666.

Carlos, A. B. and H. M. Jr. Edwards, 1997. Influence of soybean meal particle size and chlortetracycline on the utilization of phytate phosphorus by broilers. Poultry Sci., 76: (Suppl. 1) 234.

Cerniglia, G. J.; J.A.; Herbert and A. B. Watts, 1983. The effect of constant ambient temperature and ration on the performance of sexed broilers. Poultry Sci. 62.746756.

Cooper, M.A. and K.W. Washbrun, 1998. The relationships of body weight, feed consumption, and feed utilization in broilers under heat stress. Poultry Sci. 77:237-242.

Daghir, N.J., 1995. Poultry production in hot climates. Ed. N. J. Daghir, CAB International.

Drury, R.A.B., E.A. Walligton and R. Cmcrron, 1967. Carleton's Histological Technique $4^{\text {th }}$ Ed., Oxford University Press, London. U.K., pp. 33-66.

Duncan, D. B. 1955. Multiple Range and multiple F test. Biometries, 11:1-42.

El-Medany, N. M. and S. F. El-Afifi, 2002. The effect of microbial phytase on utilization of protein and phosphorus in broiler rations. Egypt. Poult. Sci. J., 22: 427- 443.

El-Nagmy, K. Y.; M. O. Abd-Elsamee and M. R. M. Ibrahim, 2004. Effect of dietary plant protein and microbial phytase levels on performance of broiler chicks. Egypt. Poult. Sci. 24: 101-121. 
Girard, M. L.; G. Ganal; G. Delattre, and J. Peynet, 1970. Technicol symposium. Paris Conference, No. 3:6.

Gordon, R. W. and SR. D. A. Roland, 1998. Influence of supplemental phytase on calcium and phosphorus utilization in laying hens. Poult. Sci. 77:290-294.

Harden, R.I. and T.P. Oscar, 1993. Thyroid hormone and growth hormone regulation of broiler adiposity lipolysis. Poultry Sci. 72: 669-676.

Hayashi, K., S. Keneda, A. Orsuka and Y. Tomita, 1992. Effect of ambient temperature and thyroxin on protein turnover and oxygen consumption in chicken skeletal muscle. Proceeding XIX World's Poultry Congress. Vol,2. Amsterdam The Netherlands. 20-24 September.

Henry, R. J.; D. C Cannon. and J. W Winkelman, 1974. Clinical Chemistry. Principles and Techniques. Harper and Row, $2^{\text {nd }} \mathrm{Ed}$.

Herms, I. H. and A.H. Al-Homidan, 2003. Effect of microbial phytase enzyme supplementation on growth performance and bone mineralization of broiler chicks reared under mild heat stress. Egypt. J. Nutrition and feeds 6: 209-224.

Hussein, A.S., 1996. Effect of dietary energy and vitamin C on growth performance of broiler chicks raised in hot climates. Emirates J. of: Agric. Sci. 8:49-62.

Ibrahim. M. R.M., 2006. Effect of different dietary levels of okra meal and microbial phytase on broiler performance. Egypt. Poult. Sci. 26: 235-246.

Kornegay, E. T., D.M. Denbow and Z. Zhang, 1997. Phytase of supplementation of corn-soybean meal broiler diets from three to seven week of age. Poultry Sci., 76: (Suppl. 1), 24.

Kornegay, E. T.;, Z. Zhang and, D. M. Denbow, 1998. Influence of microbial phytase supplementation of a low protein/amino acid diet on performance, ileal digestibility of protein and amino acids, and carcass measurements of finishing broilers. Poultry Sci., 77: (suppl. 1), S33.

Lan, G. Q., N. Abdalla, S. Jalaludin and Y.W. Ho, 2002. Efficacy of supplementation of phytase producing bacterial culture on the performance and nutrient use of broiler chickens fed corn soybean meal diets. Poultry Sci., 81: 1522-1532.

Makled, M.N.;. A. El-Deeb, Mariam and N.H. Abdallah, 2001. Effect of protein level, energy level, and season on performance of growing indigenous naked neck (Sharkasi) chickens. Egypt. Poult. Sd. 21:27-52.

Mendes, A.A., S.E Watkins., J.A England; E.A. Saleh, A.L Waldroup, P.W. Waldroup, 1997. Influence of dietary lysine levels and arginine :lysine ratios on performance of broilers exposed to heat or cold stress during the period of three to six weeks of age. Poult. Sci. 76:472-481.

Mohamed, M.A., A. E El-Sherbiny, Y.A Hammouda, F. El-Daly, Eman and H. M. A. Hassan, 2001. Effect of supplemental phytase on performance, bone characteristics and protein digestibility of broiler chicks. Egypt. J. Anim. Prod., 38: 143-156.

Moreng, R.E., 1980. Temperature and vitamin requirement of the domestic fowl. Poultry Sci. 59: 68-77.

NRC, 1994. Nutrient Requirements of Poultry. $9^{\text {th }}$ ed. National Academy of Science, Washington, DC. USA.

Onyango, E.M., M.R. Bedford and O. Adeola, 2004. The yeast production system in which Echerichia coli phytase is expressed may affect growth performance, bone ash and nutrient use in broiler chicks. Poultry Sci., 83: 421-427.

Qian, H., E.T. Kornegay and D.M. Denbow, 1996. Effects of supplemental of 
phytase and phosphorus on histological and other tibia bone characteristics and performances of broilers fed semi purified diets. Poultry Sci., 75: 618-626.

Qota, E.M. A., A.A. El-Ghamry and G. M. El-Mallah, 2002. Nutritive value of soaked linseed cake as affected by phytase, Biogen supplementation or formulating diets based on available amino acid on broiler performance. Egypt. Poult. Sci. 22: 461-475.

Reece, F.N.; J.W. Deaton,; and, L.F. Kubena, 1972. Effect of high temperature and humidity on prostration of broiler chickens. Poult. Sci. 51:2021-2025

Salem, F. M.;, H. A El-Alaily.; N. M. El-Medany and K. Abd El-Galil, 2003. Improving phosphorus utilization in broiler chick diets to minimize phosphorus pollution. Egypt. Poult. Sci. J., 79: 2134-2142.

SAS 2001. Statistical Analysis System, User's Guide Version 8.2, Cary NC. USA.

Sebastian, S., S. P. Touchburn, E. R. Chavez and P.C. Lague, 1996. The effects of supplemental microbial phytase on the performance and utilization of dietary calcium, phosphorus, copper and zinc in broiler chickens fed a corn- soybean diets. Poultry Sci., 75: 729

Shafey, T. M.;, M. W. McDonald and, J.G. Dingle, 1991. Effects of dietary calcium and available phosphorus concentration on digesta $\mathrm{pH}$ and on the availability of calcium, iron, magnesium and zinc from the intestinal contents of meat chickens. Br. Poultry Sci. 32: 185-194.

Simons, P. C. M., H. A. J Versteegh., A. W Jongbloed., P. A Kemm;, P Slump, K. D Bos, M. G. E Wolters, R. F. Beudeker and G. J. Verschoor, 1990. Improvement of phosphorus availability by microbial phytase in broilers and pigs. Br. J. Nutr., 64: 5525-540.

Soliman, A. Z. M.;, A. A Ghazalah.;, M.R El-Abbady.; MO. Abd-El-Samee, Abd-ElSamee, 1999. Broiler performance are affected by crude protein, metabolizable energy and fat during hot summer season. Egyptian J. Nutri. and Feeds ( special issue), 621-631.

Steeb, C.A, D. R Shoubridge, L. Tivey and L.C. Read, 1997. Systematic infusion of IGF-1 or LR ${ }^{3}$ IGF-1 stimulates visceral organ growth and proliferation of gut tissue in suckling rats. Am. J. Phys., 27:522-533.

Teeter, R. G., 1995. Optimizing production of heat stressed broilers. Proc. of the Inter. Conf. on Animal Prod. in Hot Climates. Muscat Sultanate of Oman, 8-10 Jan., 1995:129-137.

Teeter, R.G., M.O. Smith, S. Sangiah and F. B. Maher, 1987 Effects of feed intake and fasting duration upon body temperature and survivals of thermostressed broiler. Nutr. Rep. Inter. 35:53 1-537.

Van der Klis, J. D., H.A. J. Versteegh and P.C. M. Simons, 1996. Natuphos in laying hens nutrition. Pages 71-82 in: BASF Technical Symposium Phosphorus and Calcium Management in layers, Atlanta, GA, January 23, 1996.

Viveros, A.A., Brenes, I. Arija and C. Centeno, 2002. Effects of microbial phytase supplementation on mineral utilization and serum enzyme activities in broiler chicks fed different levels of phosphorus. Poultry Sci., 81: 1172-1183.

Watson, B., J Matthews, L. Southern and J. Shelton Shel, 2006. The effects of phytase on growth performance and intestinal transit time of broilers fed nutritionally adequate diets and diets deficient in calcium and phosphorus. Poultry Sci. 85: 493-497.

Wilson, E. K., F. W. Pierson, Y. Patricia Hester, R.L. Adams and W. I. Stadelman, 
1980. The effect of high environmental temperature on feed passage time and performance traits of White Pekin Ducks. Poultry Sci., 59:2322-2330.

Wu, Y. B., D. G Ravindran, M.J. Thomas Birtles and W.H. Hendriks, 2004. Influence of phytase and xylanase, individually or in combination on performance apparent metabolisable energy, digestive tract measurement and gut morphology in broiler fed wheat-based diets containing adequate level of phosphorus. $\mathrm{Br}$. Poultry Sci. 45: 76-84.

Wu, Y. B., V. Ravindran and W.H. Hendriks, 2003. Effects of microbial phytase, produced by solid-state fermentation, on the performance and nutrient utilization of broilers fed maize and wheat-based diets. Br. Poult. Sci., 44: 710-718.

Yalcin, S., S. Turkmut and P.B. Siegel Siegel, 2001. Response of heat stress in commercial and local broiler stocks 2. Developmental of Bilateral traits. Br. Poult. Sci. 42.153-160.

Yan, F., J.H Kersey, C.A. Fritts and P. W. Waldroup, 2001. Phosphorus requirements of broiler chicks three to six weeks of age as influenced by phytase supplementation. Poultry Sci., 80: 455-459

Yanming, H. and D. H. Baker, 1993 Effects of sex, heat stress, body weight and genetic strain on the dietary lysine requirements of broiler chicks. Poult. Sci. 72:701-708. 
إستجابة الأداء الانتاجى ومقاييس العظام والأمعاء الاقيقة ومكونات بلازما الام لمستوى الفسفور الغير عضوى ولاضافة انزيم الفيتيز الى علائق البط المسكوفى النامى فى فصل الصيف

\section{عبد العزيز سيد عثمان'، عبد الحكيم سعد عيدالحكيم'، محمد حسن فتوح'}

1- قسم بحوث تريبية الارانب والموبى والطيور المائية، معطب يحوث الانتاج الحبوانس، مركز البحوث

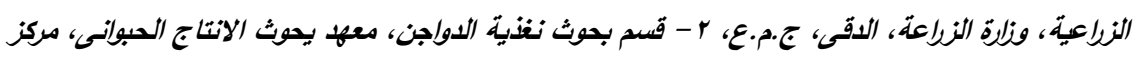

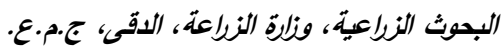

أجريت هذة الدراسة فى محطة البط بالسرو التابعة لمعهد بحوث الانتاج الحيوانى - مركز البحوث

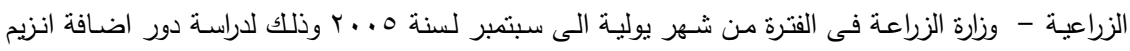

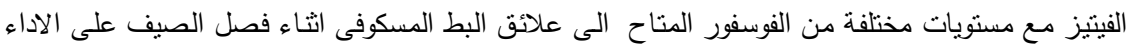

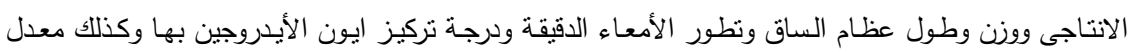

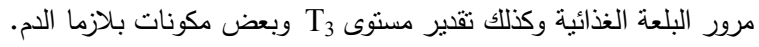

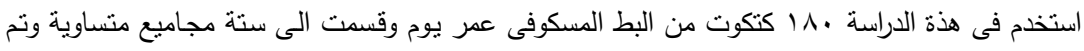

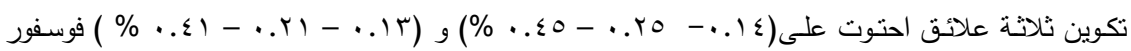

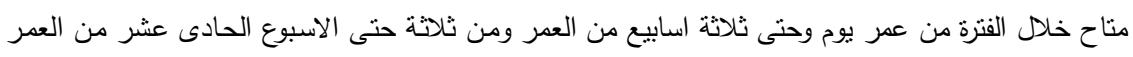

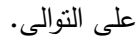

وتم اضافة انزيم الفيتيز الى كل العلائق بمعدل صفراو ل VO وحدة / كجم علف وكانت النتائج كالاتى.

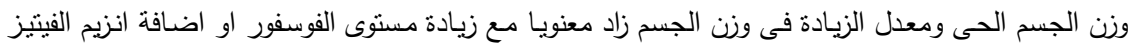

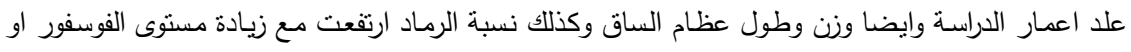
اضافة انزيم الفيتيز. وكان من اهم الننائج حدوث تحسن فى تطور الأمعاء الدقيقة ودرجة تركيز ايون الأيدروجين بها مع زيادة مستوى الفوسفور او اضافة انزيم الفيتيز خلال فصل الصيف.

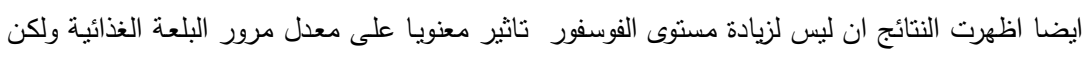

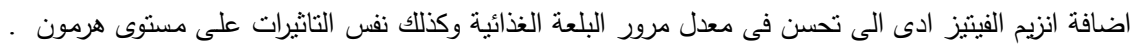

نستخلص من هذة الدراسة ان اضافة انزيم الفيتيز اثثاء فصل الصيف لنة تاثيرات مفيدة على وزن وطول

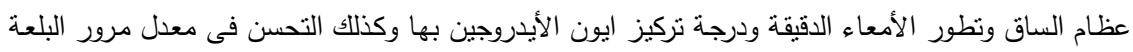

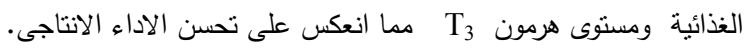

